Volume 1 Number 2

\title{
INFLUENCE OF ONLINE PORNOGRAPHY ON IN-SCHOOL ADOLESCENTS IN IMO STATE
}

\author{
Linda Nnenna Ikechukwu \\ Department of Mass Communication \\ Federal Polytechnic, Nekede, Owerri, \\ Imo State \\ linda.ikechukwu@gmail.com \\ 08033665751
}

\begin{abstract}
Juvenile access and exposure to online pornography is an alarming and escalating problem worldwide. This study attempts to find out the reasons for Internet pornography use and its influence among in-school adolescents in Imo State. To achieve these objectives, a blend of quantitative and qualitative methods of research was employed. Questionnaire and Focus Group Discussion were used to gather data for quantitative and qualitative research methods respectively. While 500 copies of the questionnaire were administered, 493 were retrieved and valid for the study, six different FGD's were constituted. Multi-stage, simple random and systematic sampling techniques were used for the selection of the respondents for the quantitative method because the population of the study cut across the three educational zones of the state and classes, purposive sampling technique was employed to select participants in the Focus Group Discussion (FGD). This technique was used to select members for the study based on their relevance to the study. The study was anchored on Social Learning and Uses and Gratification theories. Results show that in-school adolescents view online pornography to a high extent. Results also show that curiosity and fun were the primary motivations for the use of Internet pornography among in-school adolescents in Imo state. The study also found that Internet pornography corrupts their minds and makes them have wild thoughts that are capable of distracting them from their academics. Based on these results, the researcher recommends that parents should use both technical and physical strategies to monitor what their adolescent children do on the Internet
\end{abstract}

Keywords: Influence, Motivation, Use, Internet-Based Pornography, In-school Adolescents

\section{INTRODUCTION}

Unlike in the past, when pornography was found mostly in conventional forms of magazines, books and films, the Internet has become the central vehicle for the distribution of pornography, thereby, altering the ways individuals use pornography. The rise of Internet pornography is presumably because of its increased anonymity, affordability and accessibility (Carroll, Jason, Padilla-Walker, Nelson, Olson, McNamara and Madsen, 2008; Essays UK, 2018) that it provides. There are concerns about children's use of pornography, and these concerns have a long history that extends back to the Victorian era (Kendrick, 1987). In our current age, popular media discussions of the dangers of Internet pornography for children and adolescents have begun to revolve around public health conceptualizations (Kohut and Štulhofer, 2018).

Motivation has been described as an individual's inferred need, desire, or impulse which initiates, directs and sustains behaviour (Coon, 1997). It can also mean sources of purposive and goal-directed behaviour that serve "to energize and guide action towards desired ends. For one to embark on any activity or task in life, there are benefits that the individual intends to achieve. No one does anything without a purpose; likewise, adolescents must have reasons why they expose themselves to Internet pornography. 
The Internet has substantially changed the way society consumes pornographic materials and has become the most popular venue for this original purpose. However, researchers have paid little attention to why people, especially adolescents, use pornographic materials online. Arguing that the use of Internet pornography is a motivated behaviour meant to obtain what one wants to see, this study attempts to identify specific motivations for Internet pornography use. Also, the study examined the influence of Internet-based pornography on in-school adolescents in Imo State, South-East, Nigeria.

\section{STATEMENT OF THE PROBLEM}

With the penetration of the Internet into Nigeria's cyberspace in 2001, many young people are using the Internet and this has negatively led to the pronounced level of moral decadence among Nigerian youths. Porn crept into our society beginning from playboy magazine (foreign magazine), Hollywood movies through the display of sexual scenes and then the Internet. The primary carriers of porn in Nigeria are the Internet and movies. Today, Nigerian youths seem to be the largest patrons of Internet porn, apart from America. Besides viewing porn materials, they can be seen on mobile phones which come in pictures and videos (Okafor, Efetobor and Apeh, 2015).

According to the World Internet stats (2020), Nigeria ranks sixth among the top twenty nations out of the 198 countries on earth that are using the Internet. Here, Internet User is an individual, of any age, who can access the Internet at home, via any device type (computer or mobile) and connection.

To better explain the ways people use Internet pornography and further understand pornography's effects on individuals and society, it is crucial to understand what motivations drive people to use Internet pornography and how these motivations work.

There has been little attention given to examining Internet pornography use from the user's perspective (Larena and Hoeber, 2012). Few studies have explicitly attempted to understand in-school adolescents' needs or motivations driving Internet pornography use.

This study is, therefore, an attempt to investigate the potential dimensions of motivation for using Internet pornography from a communications perspective; the primary goal of this study is to identify the motivations for Internet pornography use to understand clearly its influence on individuals and the society at large with particular reference to in-school adolescents in Imo State, South East, Nigeria.

\section{RESEARCH OBJECTIVES}

$>$ To find out to what extent in-school adolescents view pornography on the Internet.

$>$ To identify reasons for Internet pornography use among in-school adolescents in Imo state.

$>$ To identify influences of exposure to Internet-based pornography on in-school adolescents in Imo State. 
$>\quad$ To what extent do in-school adolescents view pornography on the Internet?

$>\quad$ What are the reasons for Internet pornography use among in-school adolescents in Imo state?

What are the influences that exposure to Internet-based pornography has on inschool adolescents in Imo state?

\section{LITERATURE REVIEW}

\section{Internet Pornography and Adolescents}

Internet pornography is any material (either picture or word) that is sexually explicit and accessible over the Internet, primarily via websites, peer-to-peer file sharing, or Usenet newsgroups (Cowie, 2014). More than 100 million public websites host as many as 100 billion individual documents, a significant percentage of which is pornographic (Knutson, 2014).

The relationship between the Internet and pornography is symbiotic. Jonathan (2004) posits that pornography is one of the driving forces behind the expansion of the World Wide Web and on the other hand, the Internet has escalated the problem of pornography by increasing the amount of material available, the efficiency of its distribution and the ease of its accessibility (Wortley and Smallbone, 2012). While pornography had been available over the Internet since the 1980s, it was the availability of widespread public access to the World Wide Web in 1991 that led to an expansion of Internet pornography (Cowie, 2014).

Many scholars have established that adolescents have more access to the Internet. (Assael, 2005; Ballarotto, Volpi, Marzilli and Tambelli, 2018). Today's youth live in a highly sexualized media culture where the lines between pornography and popular entertainment have become increasingly blurred (MediaSmart, n.d). As one young person told the UK Office of the Children's Commissioner, "Basically, porn is everywhere" (Horvath, Miranda, Alys, Llian, Massey, Kristina, Pina, Afroditi, Scally, Mia, Adler and Joanna, 2013; MediaSmart, n.d). Even those youths who don't seek out pornography are exposed to highly sexualized content; in fact, they are more likely to encounter sexual material on TV or in music than through the Internet. Popular culture has, in general, become significantly more sexualized (MediaSmart, n.d).

Research has also shown that the most popular venue for accessing pornography is mobile or personal phones, also known as GSM or mobile devices. This popularity is because it guarantees privacy, more access and higher opportunities to view pornographic materials (Hardy, Steelman, Coyne and Ridge, 2013). One of the reasons many adolescents prefer to connect to the Internet with mobile devices rather than stationary computers is the privacy afforded by mobile devices. Mobile phones allow them to view content that, in many cases, is not monitored by authority figures such as parents and teachers (Vanden, Abeele, Campbell, Eggermont and Roe, 2014).

One of the biggest concerns voiced by parents of young Internet users is the easy access to pornography that the web provides. There are millions of porn sites online, making hardcore sexual images that were once very difficult to obtain now just a click away (MediaSmart, n.d).

There are a vast number of studies related to pornography conducted over the past years. (Essays UK, 2018; Carroll, Jason, Padilla-Walker, Nelson, Olson, McNamara and Madsen, 2008; Romito and Beltramini, 2011; Mayungbo, Sunmola, Morakinyo, Oyinola, Famakinde, 
Obosi, Opayemi, 2017). Results from these studies reflect that the Internet is the most popular form of accessing porn among adolescents. In the United States alone, $90 \%$ of adolescents aged 12 to 18 have Internet access at home, and a vast majority of them have either visited a pornographic website accidentally or intentionally at least once in their adolescent life. Studies revealed as well that since the pornographic websites are free, and the readers/viewers remain undetected or anonymous, adolescents became fond of accessing these websites (Ybarra and Mitchell, 2005; Essays UK, 2018).

The growing number of adolescents accessing porn websites on the Internet purposefully is quite alarming (Essays UK, 2018). Fifteen percent of these adolescents even resort to lying about their age to gain access to these websites (Ybarra and Mitchell, 2005).

Most pornography websites allow users access that is simple and fast with no verification of age required (DeAngelis, 2007; Wolak, Mitchell and Finkelhor, 2007; Mayungbo et al, 2017). This lack of restriction is evident in all forms of physical Internet access, including through computers, mobiles and iPods (Eberstadt and Layden, 2010; Grubbs, Wright, Braden, Wilt \& Kraus, 2019).

\section{Motivations for Internet Pornography Use}

Searching for sexually explicit material on the Internet is an intentional and purposeful behaviour. Dutta-Bergman (2003) asserts that all Internet activities are above a specific level of cognitive threshold. In other words, online activities are goal-directed and reflect the user's experiential styles (Chen, Houston, Sewell and Schatz, 1998). This indicates that people type keywords such as "sex" or "pornography" into search engines to find what they want to see, or that they $\log$ on to specific sexual sites that they believe can meet their particular motivations. There are studies in the communication field on the role of motivation to media use. In particular, the uses and gratification perspective regards the concept of the motivation behind media use as a critical factor that can account for one's media consumption (Rubin, 1983). Media Dependency Theory (MDT) also posits that one's media consumption is not accidental; instead, it is a planned and intended behaviour (DeFleur and Ball-Rokeach, 1989). It means that individuals are motivated to maintain and enhance themselves via media use. Because information is indispensable for obtaining goals, the media are an essential resource as information channels for individuals' survival or growth (Ball-Rokeach, 1998). It is common for theorists to define motivation in terms of an individual's inferred need, desire, or impulse which initiates, directs and sustains behaviour (Coon, 1997). According to McKenna, Green and Smith (2001, p. 23), motivation can be defined as sources of purposive and goaldirected behaviour that serve "to energize and guide action towards desired ends."

Batty (2004) concludes that the majority of adolescents have already come into contact with pornography on the Internet. The average age of the first exposure to adult videos is 11 years old (Knutson, 2014; Perry, 2019; Fight the New Drug, 2020).

Sexual issues and encounters relating to sexuality are still not openly discussed within the family (Essays UK, 2018). Questions and discussions on sex are still a "taboo" topic for many families in Africa such that their children seek guidance and direction from their friends rather than their parents. This leads these children to improper notions of sex and the incorrect use of their sexuality because they lack proper guidance and knowledge (Essays UK, 2018). Studies also revealed that one-third of the adolescents today have had nasty sexual comments from other people which led them to become curious about sexual matters (Batty, 2004). 
Moreover, studies revealed that the reasons why accessing pornography over the Internet were the most popular were anonymity, unlimited access and the less strict requirements of getting into a website (Batty, 2004; Essays UK, 2018).

\section{Effects of Internet Pornography on Adolescents}

The long-standing issues on pornography have been present in every generation. They have undeniably caused adverse effects on the way people viewed sexuality and their relationships to the opposite sex. As the spread of different kinds of technologies increased further, especially as the use of computers and the Internet became more prominent in the lives of the adolescents, the problems and issues on pornography worsened even more (Ybarra and Mitchell, 2005; Essays UK, 2018). The increase in access of young children and the adolescents to the use of the Internet and the viewing of pornographic sites has posed severe threats and harm over the health, psychological and social development of these people (Mesch, 2006; Essays UK, 2018).

Some may argue that watching pornography is part of the healthy sexual exploration and growth of a young person and should be encouraged, but Powell (2015) describes the critical highlights of a TED talk by Gary Wilson, a retired neurologist. The discussion was titled "The Great Porn Experiment." In the video, Wilson details the devastating effects of long term consumption of pornography on the developing brain including, Attention Deficit Disorder (ADD), Obsessive Compulsive Disorder (OCD), social anxiety and depression. Wilson (2013) opined that pornography also numbs the ability to feel real-life intimacy. The longer a brain is exposed to pornography, the more hyperactive it becomes at the sight of pornography. In other words, the more one views pornography, the more the brain desires it. It is a vicious cycle that ultimately erodes one's willpower and self-control.

Some scholars have argued that most kids at a tender age do not understand the content of these pornographic materials; hence they cannot be affected by what they do not understand (Orlowski, 2012; Oyedunni, 2016). But other scholars are of the view that if young children can't understand sex or its role in relationships, the images they see can leave a lasting impression on them. This is due to a concept known as neuroplasticity (Gomez, 2008; Armstrong, Quadara, El-Murr and Latham, 2017).

Neuroplasticity is the process by which a human brain creates new neural networks by continually reorganizing itself. This means that one's brain is constantly optimizing itself to perform efficiently despite any loss of brain function due to age, injury, etc. (Beck, 2017). One of the known components of neuroplasticity is that as one age, his brain becomes less plastic and resists change at a higher degree than when he was younger. This is especially true for children: neuroplasticity is at its highest during childhood and adolescent phases, then decreases continually for the remainder of one's lives. Our children's brains are shaped by their experiences, and those experiences determine much of their character throughout their lives. So, due to the high neuroplasticity, any values or ideas that are learned from pornography will have a lasting impact on children's lives if they are not addressed appropriately (Beck, 2017).

Outside of poor moral judgments about pornography, some research has indicated that compulsive pornography viewing can have significant effects in an adolescent's life (Rossi, 2002).

\section{THEORETICAL FRAMEWORK}


The study anchors on Social Learning and Uses and Gratification theories. Social Learning Theory (SLT), also known as the Observational Learning theory. The core tenets and basic assumptions of the theory were formulated by Albert Bandura. According to Bandura and the supporters of SLT, people learn new information and behaviours by watching and mimicking. They argue that behaviours are learnt through direct observation and internalization. SLT asserts that behaviours are usually triggered by some antecedents like observation and watching that often lead to imitation of the observed behaviour through the process of retrieval, rehearsal, or training (Ali and Nafiu, 2018).

In this study, the theory is useful in understanding how exposure to Sexually Explicit Materials can affect adolescents. Bandura, 1978 in Asemah, Nwammuo and NkwamUwaoma, 2017; Ali and Nafiu, 2018 posits that learning from the new media is largely dependent on a series of mental processes that include attention, retention, motor reproduction and motivation. Through the media, adolescents not only learn what is likely to be the outcome of sexual activity, but also consciously engage in it or approve of it and come to see themselves as able to participate in similar activities themselves (Ali and Nafiu, 2018). Although SLT provides an avenue to understand the relationship between observation and learning, it fails to give the motivational forces for imitation. The Uses and Gratification theory addresses this gap (Ali and Nafiu, 2018).

Uses and Gratification theory (UGT) is traced to the 1940s when researchers in the United States became interested in reasons for viewing the media. Studies conclude that different people use the media for different motivations and purposes (Asemah, Nwammuo and Nkwam-Uwaoma, 2017; Ali and Nafiu, 2018). Elihu Katz first introduced the UGT and developed by Jay Blumler and Michael Gurevitch. The theory submits that people use the media and its contents to their benefits. This theory is contemporary as it contradicted older views that assumed the audience was a passive group (Asemah, Nwammuo and NkwamUwaoma, 2017). The UGT approach views the audience as active; meaning that they actively seek out specific media and its content to achieve precise results or gratifications that satisfy their personal needs (Rossi, 2002). It presents the use of media in terms of the satisfactions of social or psychological needs of the individual (Katz, Blumler and Gurevitch, 1974, cited in Chandler, 1994).

The Uses and Gratification theory provides a framework for explaining audience motivations for media usage (Oguche, 2014). Also, Katz, Gurevitch and Haas (1973) corroborate with Folarin (1998) when they argued that studies of media "uses and gratifications" are ultimately an effort to understand effects. Since the objectives of this study are to find out the motivations for the use of Internet pornography and to identify the various ways in which Internet-based pornography affects in-school adolescents in Imo State among other objectives, the researcher is optimistic that the Uses and Gratification theory will serve as a good foundation for this study.

\section{METHODOLOGY}

The study employed a mixed-method comprising a quantitative and qualitative design. Whereas the quantitative design made use of a survey, the qualitative design used focus group discussions (FGD). The survey and focus group discussion played complementary roles. The rationale is not only to compensate weakness in a method with the strength of the other but also to substantiate statistical findings with the original statement of responden 
(Frey, Botan and Kreps, 2000, p. 222). While the survey gives a researcher the opportunity to study people's opinion on a given issue of public importance, the focus group discussion allows a researcher to study the respondents in a more natural conversational pattern. The strength of FGD lies in allowing the participants to agree or disagree with each other so that it provides an insight into how the group thinks about an issue. Furthermore, the researcher intends to use FGD as it can explore the meaning of survey results that cannot be explained statistically, the range of opinions/views and to collect a wide range of local terms.

The study area is Imo state. Imo state was chosen as it is an educationally high-achieving state which has over the years been one of the states that produced the highest number of candidates in Nigeria for external examinations such as JAMB, WAEC and NECO. For instance, Imo state has produced the highest number of candidates in the Joint Admissions and Matriculation Board (JAMB) for many years (Abah, 2016; Erunke, 2018). The state is therefore assumed to have adolescents who are Internet and ICT savvy. The state has twentyseven local government areas in three educational zones. The three educational zones are Owerri, Orlu and Okigwe educational zones.

According to the Open Registry of the Ministry of Education, Owerri, the population of students for the 2018/2019 academic year from 260 government-owned secondary schools and 328 government-approved private secondary schools in Imo state stands at 460,742. Out of this number, 500 students were chosen as the sample for the study. The sample size was arrived at in line with the submissions of Comrey and Lee (1992) rating scale of sample size adequacy: $100=$ poor, $200=$ fair, $300=$ good, $500=$ very good, 1,000 or more $=$ excellent . The study adopted the multi-stage sampling technique involving simple random, systematic and convenience sampling techniques respectively. The sampling went through five stages. In the first stage, two local governments were chosen using simple random sampling through the table of random numbers from the three educational zones in the state. In stage two, one public (government-owned) and one government-approved private secondary school were selected from the local government areas selected in stage one using simple random sampling techniques. Here, again the table of random numbers was employed to select secondary schools from the local government areas selected in stage one. In stage three, simple random sampling was used to draw one class from the junior section i.e. JS 1-JS3 of the secondary schools picked in stage two and J.S. 2 was picked. In stage four, simple random sampling was also used to pick one class from the senior section i.e. SS1-SS3 of the secondary schools picked in stage two and SS 3 was picked.

At the last stage, a systematic sampling method was employed to pick students from the official class list of JS 2 and SS 3 of all the selected secondary schools in the three educational zones in the state. Twelve schools were selected; the researcher also selected two classes in these twelve schools. This means that twenty-four classes were used for the study and sixteen samples were studied in each class selected. This allocation is gotten by dividing the sample by the total number of classes selected. That is 500/24 $=20.8333$ app. 21 .

According to the Open Registry of the Ministry of Education, there are at least forty students in four streams of a class totalling one hundred and sixty students in public (governmentowned) secondary.

Based on the above facts, the nth student in each of the schools was gotten by dividing the total number of students in a class by the class allocation thus: Nth student of public (government) owned secondary schools: $\quad 160 / 21=7.6=8$ (app.) 
Volume 1 Number 2

Hence, one student was selected from the official class list at intervals of 8 beginning from the $1^{\text {st }}$ student on the class list. This continued until a total of 21 students were gotten for that class.

The researcher used the convenience sampling procedure to convene six focus group discussion sessions with at least eight to ten discussants per session. A structured questionnaire and focus group discussion guide were the data collection instruments for the survey and FGD respectively. Quantitative data analysis employed simple percentages as well as mean scores and standard deviation scores. In contrast, a descriptive thematic method was used to analyse the qualitative data for the analyses of the qualitative data.

\section{DATA PRESENTATION AND ANALYSIS OF RESULTS}

Out of 500 copies of the questionnaire administered to respondents in Imo State, 493 (98.6\%) were returned and found useful for data analysis, thus giving the questionnaire a mortality rate of $7(1.4 \%)$.

Table 1: $\quad$ Distribution of responses showing socio-demographic data of respondents

\begin{tabular}{lllll}
\hline S/N & Variables & & Frequency & Percentage (\%) \\
\hline 1. & Age & $11-13$ years & 92 & 18.7 \\
& & $14-16$ years & 245 & 49.7 \\
& & $17-19$ years & 156 & 31.6 \\
2. & \multirow{2}{*}{ Gender: } & Male & 268 & 54.4 \\
& & Female & 225 & 45.6 \\
3. & \multirow{2}{*}{ Present Class: } & JSS 1 -3 & 235 & 47.7 \\
& & SS 1 -3 & 258 & 52.3 \\
\hline & & 493 & 100
\end{tabular}

Source: Field Survey, 2019

The demographic data of respondents (i.e. in-school adolescents) shows that in-school adolescents between 14-16 years were predominant with $49.7 \%$. They were closely followed by those between 17-19 years with $31.6 \%$. Those 11-13 years made up 18.7 per cent of the respondents. Also, there is a preponderance of male in-school adolescents representing $54.4 \%$ when compared to their female counterpart $45.6 \%$ of the total respondents. The table on the present class of respondents showed that most of them were in the Senior Secondary classes as the data present 258, representing $52.3 \%$ in SS classes and 235, representing $47.7 \%$ in JS classes.

Research Question One: To what extent do in-school adolescents view pornography on the Internet?

Table 2: $\quad$ Distribution of responses showing respondents' access to the Internet

\begin{tabular}{lllll}
\hline S/N & Variables & Responses & Frequency & Percentage (\%) \\
\hline 1. & Do you have access to the & Yes & 372 & 75.5 \\
Internet? & No & 114 & 23.1 \\
& Undecided & 7 & 1.4 \\
\hline Total & & 493 & 100 \\
\hline Source: Field Survey, 2019 & & & \\
& & &
\end{tabular}


Volume 1 Number 2

Table 2 shows that majority of the respondents have access to the Internet. This implies that they can answer the questions of the study.

Table 3: Distribution of responses showing respondents exposure to sexually-explicit contents

\begin{tabular}{lllll}
\hline S/N & Variables & Responses & Frequency & Percentage (\%) \\
\hline 1. & Since you have access to the & Yes & 312 & 83.9 \\
& Internet, have you ever come No & 45 & 12.1 \\
across sexually-explicit contents? & I don't know & 15 & 4 \\
\hline Total & & 372 & 100 \\
\hline
\end{tabular}

Source: Field Survey, 2019

Table 3 clearly shows that majority of the respondents have come across sexually-explicit contents on the Internet.

Table 4: Distribution of responses showing respondents opinion on their first exposure to pornography

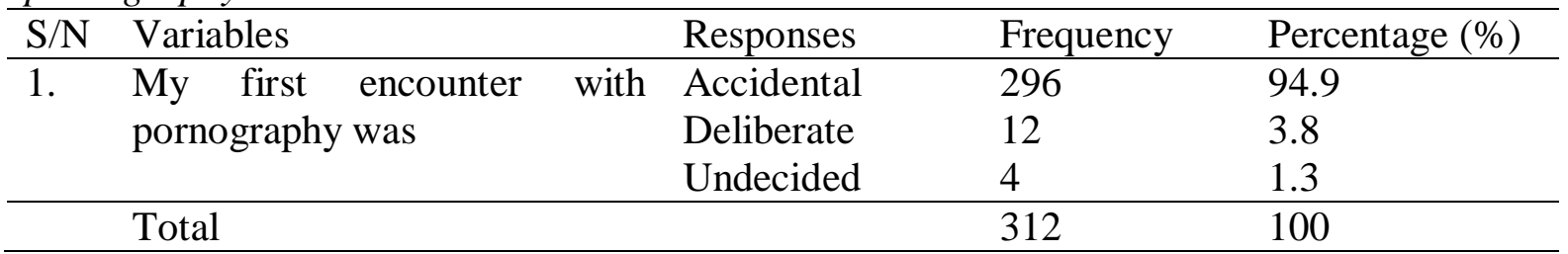

Source: Field Survey, 2019

Table 4 shows that most respondents' first encounter with pornography on the Internet was accidental; they did not deliberately go in search for it.

Table 5: Distribution of responses showing respondents' frequency of viewership of pornography online

\begin{tabular}{llllll}
\hline S/N & Variables & Responses & Frequency & Percentage (\%) \\
\hline 1. & How often do you view & Always & 82 & 26.3 \\
& $\begin{array}{l}\text { pornography anytime you go } \\
\text { online? }\end{array}$ & Occasionally & 177 & 56.7 \\
& Never & 53 & 17 \\
\hline & & & 100 \\
\hline
\end{tabular}

Source: Field Survey, 2019

Table 5 shows that majority of the respondents view pornography on the Internet occasionally (56.7\%) while $26.3 \%$ of the respondents view it always. The least of all is $17 \%$ of the respondents who NEVER view pornography online. The picture, however, suggests that most respondents view pornography be it occasionally or always.

Research Question Two: What are the reasons for Internet pornography use among in-school adolescents in Imo state?

Table 6: Distribution of responses showing reasons for Internet pornography use among respondents

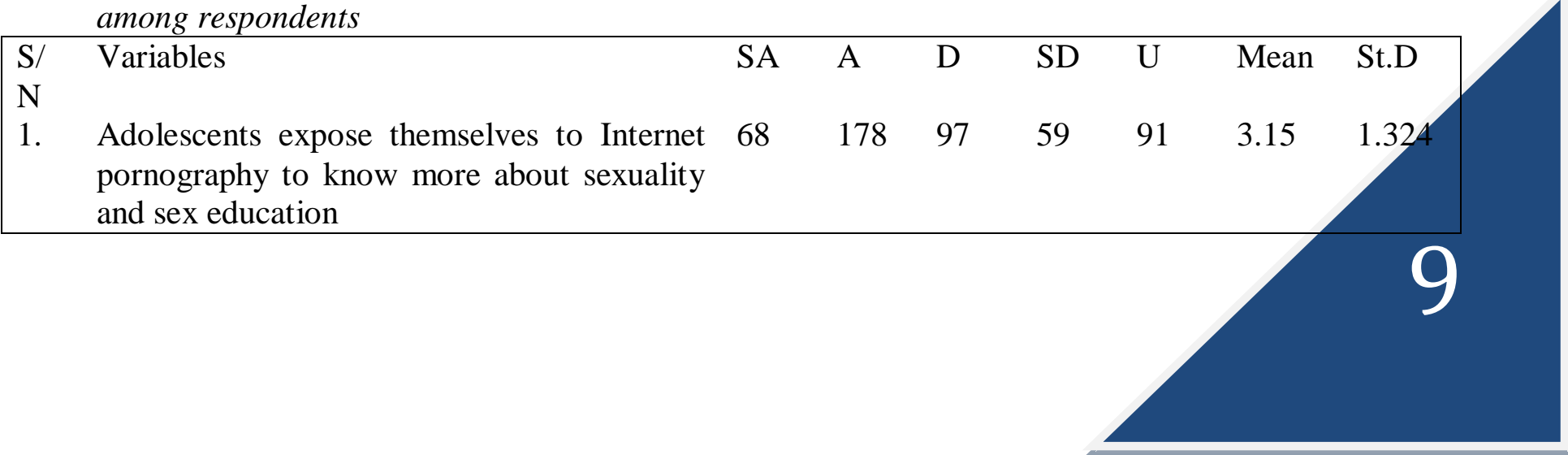


2. Adolescents expose themselves to Internet

\begin{tabular}{lllllll|}
64 & 228 & 46 & 50 & 85 & 3.36 & 1.346 \\
33 & 103 & 47 & 151 & 159 & 2.39 & 1.306 \\
& & & & & & \\
23 & 61 & 130 & 188 & 91 & 2.47 & 1.071 \\
& & & & & & \\
59 & 82 & 104 & 120 & 128 & 2.89 & 1.280 \\
59 & 120 & 104 & 128 & 82 & 2.89 & 1.280 \\
73 & 133 & 94 & 109 & 84 & 3.00 & 1.330 \\
\hline
\end{tabular}

pornography to satisfy their curiosity on some issues they can't discuss with their parents or teachers

3. Adolescents expose themselves to Internet pornography because they see it as an adventure

4. Adolescents expose themselves to Internet pornography due to peer pressure / influence

5. Adolescents expose themselves to Internet pornography to satisfy their sexual desires

6. Internet pornography is educative

7. Internet pornography is entertaining / fun Source: Field Survey, 2019

The limit of a real number is used as a basis to determine the cut-off point for each level of measurement. Those responses that have mean scores within the range of the limits set for each range of analysis are named by those ranges of measurement. Here is a run-down of the limits set for real numbers that fall within each scale of measurement.

\begin{tabular}{|c|c|c|c|c|}
\hline For "Strongly Agree decision & $=$ & $(5.00-4.45)$ & $=$ & 5point \\
\hline For "Agree decision & $=$ & $(4.44-3.45)$ & $=$ & 4point \\
\hline For "Disagree" decision & $=$ & $(3.44-2.45)$ & $=$ & 3point \\
\hline For "Strongly Disagree" decision & $=$ & $(2.44-1.45)$ & $=$ & 2 point \\
\hline For "Undecided" decision & $=$ & $(1.44-0.45)$ & $=$ & 1point \\
\hline
\end{tabular}

The result in Table 6 shows a preponderance of decisions tilting towards "Disagree" based on the above benchmark called "Limit of real numbers".

From the result, all the responses fall within the "Disagree" decision as indicated in the figures under " $\mathrm{D}$ " column (i.e. 3.44 - 2.45). Majority of the respondents agree that adolescents expose themselves to Internet pornography to know more about sexuality and sex education. A higher number of them also agree that adolescents expose themselves to Internet pornography to satisfy their curiosity on some issues they can't discuss with their parents or teachers. However, a higher number of the respondents were undecided about adolescents exposing themselves to Internet pornography for adventure and to satisfy their sexual desires. Furthermore, a majority of them strongly disagree that adolescents expose themselves to Internet pornography due to peer pressure / influence and Internet pornography is educative. At the same time, a higher number of respondents agree that Internet pornography is entertaining / fun.

The classification of all the responses into the 'Disagree' decision (3.44-2.45) is because most of the respondents are undecided in their responses. The reason for this is not farfetched as these respondents are still very young and or maybe naïve and shy to admit some of these motivations.

Research Question Three: What are the influences that exposure to Internet-based pornography has on in-school adolescents in Imo state? 
Volume 1 Number 2

Journal OF COMMUNICATION AND MEDIA STUDIES

Table 7: Distribution of responses showing the effects of Internet pornography on the developmental processes of respondents

\begin{tabular}{|c|c|c|c|c|c|c|c|c|}
\hline $\begin{array}{l}\mathrm{S} / \\
\mathrm{N}\end{array}$ & Variables & SA & $\mathrm{A}$ & $\mathrm{D}$ & SD & $\mathrm{U}$ & Mean & St.D \\
\hline 1. & $\begin{array}{l}\text { Adolescents who expose themselves to } \\
\text { Internet pornography are more likely to have } \\
\text { sex earlier than they should }\end{array}$ & 135 & 182 & 58 & 67 & 51 & 3.570 & 1.299 \\
\hline 2. & $\begin{array}{l}\text { Adolescents who expose themselves to } \\
\text { Internet pornography are more likely to have } \\
\text { feelings of dissatisfaction with one's body } \\
\text { and sexual anxiety }\end{array}$ & 124 & 212 & 52 & 54 & 51 & 3.620 & 1.258 \\
\hline 3. & $\begin{array}{l}\text { Exposure to Internet pornography can } \\
\text { generate anxiety, confusion, weak social } \\
\text { bonds and addictions in adolescents }\end{array}$ & 152 & 183 & 60 & 30 & 68 & 3.650 & 1.340 \\
\hline
\end{tabular}

Source: Field Survey, 2019

The limit of real number is used as a basis to determine the cut-off point for each scale of measurement. Those responses that have mean scores within the range of the limits set for each scale of measurement are named by those scales of analysis.

The result in Table 7 shows a preponderance of decisions tilting towards "Agree" based on the above benchmark called "Limit of real numbers".

From the result, all the responses fall within the "Agree" decision as indicated in the figures under "A" column. Hence, respondents agree that adolescents who expose themselves to Internet pornography are more likely to have sex earlier than they should, have feelings of dissatisfaction with their body and experience sexual anxiety. Lastly, exposure to Internet pornography can generate anxiety, confusion, weak social bonds and addictions in adolescents.

The responses that rank highest in the "Agree" decision were: exposure to Internet pornography can generate anxiety, confusion, weak social bonds and addictions in adolescents $($ mean $=3.650$, St. Dev. $=1.340)$. It was followed by adolescents who expose themselves to Internet pornography are more likely to have feelings of dissatisfaction with one's body and sexual anxiety (Mean $=3.620$, St. Dev. $=1.258)$. The least in the table are adolescents who expose themselves to Internet pornography are more likely to have sex earlier than they should $($ Mean $=3.570$, St. Dev. $=1.299)$.

\section{Results from the Focus Group Discussion (FGD)}

A total of 6 focus group discussion sessions took place in six secondary schools drawn from the three educational zones in Imo State. The focus group discussion addressed the three research questions and played a complementary role in the survey. One public and one private secondary school were selected from the educational zones. The FGD guide had twelve questions.

The strength of FGD lies in allowing the participants to agree or disagree with each other so that it provides an insight into how the group thinks about an issue. Furthermore, the researcher used the FGD to explore the meaning of survey findings that cannot be explained statistically, the range of opinions/views and to collect a wide range of local terms. 
From the six sessions, the discussants agreed and disagreed but at the end, some resolutions were made. The first research question wanted to find out the extent to which in-school adolescents view pornography on the Internet. Discussants agreed that they have Internetenabled gadgets through which they have come across pornographic materials. For most of them, their first encounter was unintentional rather than deliberate. The discussants also revealed that after their first accidental encounter with pornography on the Internet, they deliberately visit pornographic sites. Also, most of the discussants visit these sites once in a while and spend not less than one hour on these sites. Based on these, it is evident that these discussants viewed pornography to a high extent since they deliberately visit pornographic sites frequently visit these sites spending not less than one hour on the sites.

The second research question asked about the reasons for Internet pornography use among inschool adolescents. The discussion with the students saw them enumerating a lot of reasons for Internet pornography use among these in-school adolescents. Among the reasons mentioned, the primary motivation for use of Internet-based pornography is fun followed by adventure and then to satisfy curiosity. These results, however, disagree with a study carried out by Igyuve and Agbele (2018) on undergraduates of Nassarawa State University, Keffi on the gratifications derived from Internet pornography. The study found out that sexual gratifications were the primary gratification derived from exposure to Internet pornography. Other gratifications included stress relief, learning new sexual techniques, mere sexual arousal and strengthening family lives, particularly if viewed with one's partner. The variance in results of the two may be evident in the fact that undergraduates are more matured and have passed through various hurdles of life, unlike in-school adolescents who are still at a very early part of their lives.

The third research question which sought to find out the influences that exposure to Internetbased pornography has on in-school adolescents was highly revealing in the focus group discussion. Discussants were of the view that exposure to Internet pornography affects them in several ways with corrupt minds/wild thoughts taking majority closely followed by distraction from their academics and imitation among other ways.

These were some of the excerpts from the focus group discussion on this research question:

“...it makes one absent-minded. While a teacher is teaching, one may be imagining what the teacher will look like when naked instead of paying attention to what the teacher is teaching..."

\section{(Focus Group Discussion, $21^{\text {st }}$ November 2019, 1. 15pm)}

"...pornography makes adolescents have wild and negative thoughts all the time. When someone makes a statement, the person will interpret it negatively. The person's mind is already polluted by pornography. For instance, a physics teacher teaching the law of motion says that when the inward force is directly proportional to the force applied and then my friend interpreted it negatively to our surprise..."

\section{(Focus Group Discussion, $2^{\text {th }}$ November 2019, 12. 36pm)}

\section{CONCLUSION}

The study examined how Internet pornography influences in-school adolescents and what motivates them to use Internet pornography. Based on the result of the study, the researcher concludes that about $80 \%$ of respondents who have access to the Internet have come across sexually explicit contents and visit porn sites after the first accidental encounter. Data fr 
the study also show that in-school adolescents in Imo state use the Internet for the desire for knowledge and fun. At the same time, it affects their developmental processes physically, academically and psychologically. It however, leads to the conclusion that in-school adolescents' access to the Internet enhances their exposure to sexually explicit contents. Also, exposures to such pornographic contents influence the developmental processes of these adolescents despite their motivations for use.

\section{RECOMMENDATIONS}

- Parents should make use of parental control software to monitor what their adolescent children do on the Internet. Companies now market new tools to track where children go online, who they meet there and what they do. Such parental control software includes Net Nanny, Family Time, OurPact, Norton Family Premier, Web Watcher etc. Parents can also block or control on an app-by-app basis, apply Internet filters, monitor calls and texts and keep an eye on contact lists.

- Parents should create time to go through the Internet browser history and photo galleries of their adolescents' phones from time to time and unannounced too.

- Since no filter is $100 \%$ effective, parents and teachers should establish an environment of open communication, where the adolescent is encouraged to take the lead in terms of their unpleasant experiences on the Internet. They should endeavour to discuss issues on sex and sexuality from an early age with their children since a majority of respondents submitted that they go to porn sites to satisfy their curiosity in some matters that they cannot discuss with their parents or teachers.

- Parents should discourage the use of mobile phones for their adolescent children. The Internet has potentials, and it is mostly used for homework by adolescents, there should be a desktop or laptop connected to the Internet and situated in a central place where these adolescents can do their assignments, thereby, making it less personalized.

\section{REFERENCES}

Abah, C. (2016, June 14). Imo has highest number of UTME candidates. Punch. Retrieved from https://punchng.com/imo-highest-number-utme-candidates/

Ali, A.A. \& Nafiu, T.A. (2018). New Media and Adolescents' Sexual Behaviour in SubSahara Africa: Linking Theories to Realities. Sage Journal, 8(4). Retrieved from:https://doi.org/10.1177/2158244018804606.

Asemah, E.S., Nwammuo, A.N. \& Nkwam-Uwaoma, A.O.A. (2017). Theories and models of communication. Jos: Jos University Press.

Assael, H. (2005). A Demographic and Psychographic Profile of Heavy Internet Users and Users by Type of Internet Usage. Journal of Advertising Research. 45. 93-123. $10.1017 /$ S0021849905050014.

Ball-Rokeach, S. (1998). A Theory of Media Power and a Theory of Media Use. Retrieved from: https://www.tandfonline.com/doi/ abs/10.1080/15205436.1998.9676398.

Ballarotto, G., Volpi, B., Marzilli, E. and Tambelli, R. (2018). Adolescent Internet Abuse: A Study on the Role of Attachment to Parents and Peers in a Large Community Sample. BioMed Research International. 2018. 1-10. 10.1155/2018/5769250. 
Batty, D. (2004, November 26). Grooming law is unworkable, police warn. The Guardian, p.12.

Beck, J. (2017). How Pornography Affects Teenagers (and Children). Retrieved from: https://everaccountable.com/blog/category/for-men/

Carroll, J.S., Padilla-Walker, L.M., Nelson, L.J., Olson, C.D., Barry, C.M. \& Madsen, S.D.(2008). Generation XXX: Pornography Acceptance and Use Among Emerging Adults. Journal of Adolescent Research, 23(1), 6-30.

Chandler, D. (1994). Why do people watch television? Retrieved from http://visual memory.co.uk/daniel/Documents/short/usegrat.html.

Chen, H., Houston, A., Sewell, R. R., \& Schatz, B. R. (1998). Internet browsing and searching: User evaluations of category map and concept space techniques. Journal of the American Society for Information Science, 49(2), 582-603.

Comrey, A. L. and Lee, H. B. (1992).A first course in factor analysis. Hillsdale, NJ: Erlbaum.

Coon, D. (1997). Essentials of Psychology: Exploration and Application, 7th ed. Pacific Grove, CA: Brooks/Cole Publishing Company.

Cowie, J. (2014). The deadly challenge of Internet porn and social media websites. The deadly challenge of internet porn. Retrieved from:

https://rugbychristadelphians.blogspot.com/2014/01/the-deadly challenge-ofinternet porn_7.html

DeAngelis, T. (2007). Web pornography's effect on children. Monitor on Psychology, 38(10), 50-65. Retrieved from https://www.tricitypsychology.com/web-pornographyseffect-on children/

DeFleur, M. L., \& Ball-Rokeach, S. (1989). Theories of mass communication. New York: Longman.

Dutta-Bergman, M. (2003). Health communication on the web: The roles of web use motivation and information completeness. Communication Monographs, 70(5), 264- 274 .

Eberstadt, M. and Layden, M. A. (2010). The Social Costs of Pornography: A Statement of Findings and Recommendations. USA: The Witherspoon Institute.

Erunke, J. (2018, March 8). Imo leads with 92,890 candidates as 2018 UTME begins. Vanguard. Retrieved from https://www.vanguardngr.com/2018/03/imo-leads92890-candidates 2018-utme-begins/ 
Volume 1 Number 2

Essays, UK. (November 2018). The Adverse Effects of Pornography Sociology Essay. Retrieved from https://www.ukessays.com/essays/sociology/the-adverse-effects-of pornography-sociology-essay.php?vref=1

Fight the New Drug (2020). What's The Average Age of a Child's First Exposure To Porn? Available at https://fightthenewdrug.org/real-average-age-of-first-exposure/

Folarin, B. (1998). Theories of mass communication: An introductory text. Ibadan: Stirling Horden.

Frey, L. R., Botan, C. H. and Kreps, G. L. (2000). Investigating communication: An introduction to research method. Boston: Allyn and Bacon.

Gomez, R.A. (2008). Protecting Minors from Online Pornography without Violating the First Amendment: Mandating an Affirmative Choice, 11 SMU Sci. \& Tech. L. Rev. 1 https://scholar.smu.edu/scitech/vol11/iss1/2

Grubbs, J. B., Wright, P. J., Braden, A., Wilt, J. A., \& Kraus, S. W. (2019) Internet pornography use and sexual motivation: A systematic review and integration. Annals of the International Communication Association.http://dx.doi.org/10.1080/23808985.2019.1584045

Hardy, S. A., Steelman, M. A., Coyne, S. M. and Ridge, R. D. (2013). Adolescent religiousness as a protective factor against pornography use. Journal of Applied Developmental Psychology,34(3), 131-139. Retrieved from: https://doi.org/10.1016/j.appdev.2012.12.002

Horvath, Miranda A. H. and Alys, Llian and Massey, Kristina and Pina, Afroditi and Scally, Mia and Adler, Joanna R. (2013). Basically... porn is everywhere: a rapid evidence assessment on the effects that access and exposure to pornography has on children and young people. Project Report. Office of the Children's Commissioner for England, London, UK.

Igyuve, A. and Agbele, J.D. (2018). Internet pornography gratification among youths: A study of Nasarawa State University, Keffi. Elk Asia Pacific Journal of Social Science, 4(2). DOI:10.16962/EAPJSS/

Jonathan, J. M. L. (2004). "Cyberporn, Sexuality and the Net Apparatus", Convergence: The International Journal of Research into New Media Technologies, 10(1), 43-65. $10.1177 / 135485650401000104$

Katz, E., Gurevitch, M. and Haas, H. (1973). On the use of the mass media for important things. American Sociological Review, 38(2), 164-181.

Retrievedfrom https://repository.upenn.edu/asc_papers/267

Katz, E., Blumler, J.G. and Gurevitch, M. (1974). Utilization of mass communication by theindividual.In J.G. Blumler and E. Katz (Eds.). The uses of mass communication: Current perspectives on gratifications research (pp.152-180). Beverly Hills, CA: Sage. 
Volume 1 Number 2

Kendrick, W. (1987). The secret museum: Pornography in modern culture. New York: Viking.

Knutson, C.D. (2014). Internet Pornography: Digital Mists of Darkness. Retrieved from http://digitalmists.com/read/chapter-4/

Kohut, T. \& Štulhofer. A. (2018). Is pornography use a risk for adolescent well-being? An examination of temporal relationships in two independent panel samples. PLoS ONE 13(8). Retrieved from: https://doi.org/10.1371/journal.pone.0202048

Larena, H. \& Orland, H. (2012). Determinants of an Innovation Process: A Case Study of Technological Innovation in a Community Sports Organization. Journal of Sport Management, 26(3),213-223.

Mayungbo, O.A., Sunmola, A.M., Morakinyo, A., Oyinlola, A., Famakinde, O. \& Obosi, A., Opayemi, A.S.(2017). Consumption of pornographic material, gender differences and HIV risky sexual behaviour. British Journal of Psychology Research, 5(3), pp 12-26.

McKenna, K. Y. A., Green, A. S., \& Smith, P. K. (2001). Demarginalization of the sexual self. $\quad$ The Journal of Sex Research, 38(3), 302-311.

MediaSmart (n.d). Pornography - Overview. Retrieved from: https://mediasmarts.ca/digital media literacy/digital-issues/pornography/pornography-overview

Mesch, G.S. (2006). Family characteristics and intergenerational conflicts over the Internet. Information, Communication \& Society, 9(4), 473-495.

Oguche, E.N. (2014). Nigerian university students' Internet uses and gratifications: Study of two selected Internet access points. Unpublished M.Sc Thesis. Department of Mass Communication, Ahmadu Bello University, Zaria.

Okafor, C.O., Efetobor, O.E. \& Apeh, A.C. (2015). An evaluation of the correlation between Internet pornography and the sexual behaviour of Nigerian undergraduates. Communication Panorama: African and Global Perspectives, 1(1). Maiden Issue.

Orlowski, J. (2012). "Beyond Gratification: The Benefits of Pornography and the Demedicalization of Female Sexuality." The Modern American 8(2), 53-71.

Oyedunni, S. A., Ogbu, I.A. and Dipeolu, I.O. (2016). Influence of Internet use on sexualbehaviour of young persons in Ibadan North Local Government Area, Oyo State, Nigeria. The Pan African Medical Journal. Retrieved from: http://www.panafrican-med journal.com/content/article/25/261/full

Perry, K. (2019). What's the average age kids see Internet pornography? (quite young). Available at https://www.westandguard.com/what-s-the-average-age-kids-see Internet-pornography-quite-young

Romito, P. and Beltramini, L. (2011). Watching pornography: gender differences, violence and victimization. An exploratory study in Italy. Violence against women.17(10) 1313- 1326. 
Rossi, E. (2002). Uses and gratifications/dependency theory. Retrieved from http://zimmer.csufresno.edu/johnca/spch100/7-4-uses.htm.

Rubin, A. M. (1983). Television uses and gratifications: The interactions of viewing patterns and motivation. Journal of Broadcasting, 27(2), 37-51.

Vanden, Abeele, M. K., Campbell, S. W., Eggermont, S. \& Roe, K. (2014). Sexting, mobile porn use and peer group dynamics: Boys' and girls' self-perceived popularity, need for popularity and perceived peer pressure. Media Psychology, 17(1).DOI: 10.1080/15213269.2013.801725.

Wolak, J., Mitchell, K. and Finkelhor, D. (2007).Unwanted and wanted exposure to onlinepornography in a national sample of youth Internet users. Paediatrics, 119(2), $247-257$.

World Internet Stats (2020). Top 20 countries with the highest number of Internet users. Retrieved from: https://www.Internetworldstats.com/top20.htm

Wortley, R. and Smallbone, S. (2012). Child pornography on the internet. ProblemOrientedGuides for Police problem-specific guides Series No. 41. Retrieved from:www.justiceacademy.org https://www.justiceacademy.org/i Share/LibraryCOPS/cops-p104 pub.pdf.

Ybarra, M. L. and Mitchell, K. J. (2005). Exposure to Internet pornography among children and adolescents: A national survey. Journal of Cyberpsychology \& Behaviour, $8(5), 473-\quad 486$. 